\title{
Inventions Related to Gamification Can Be Patented in Brazilian Patent Office
}

\author{
Ricardo Fontes Macedo ${ }^{1 *}$, Washington Sales ${ }^{1}$, Alan Malacarne ${ }^{1}$, Camila Souza Vieira1, \\ Liária Nunes da Silva² ${ }^{2}$ Claudia Cardinale Nunes Menezes ${ }^{1}$, Robelius De-Bortoli ${ }^{*}$ \\ ${ }^{1}$ Postgraduate Program in Intellectual Property Science, Sergipe Federal University, Sergipe, Brazil \\ ${ }^{2}$ Postgraduate Program in Intellectual Property Science, Piauí Federal Institute, Piauí, Brazil \\ Email: *ricardo10fontes@gmail.com, *robelius@yahoo.com.br
}

How to cite this paper: Macedo, R. F., Sales, W., Malacarne, A., Vieira, C. S., da Silva, L. N., Menezes, C. C. N., \& De-Bortoli, R. (2018). Inventions Related to Gamification Can Be Patented in Brazilian Patent Office. Creative Education, 9, 1054-1060. https://doi.org/10.4236/ce.2018.97078

Received: April 23, 2018

Accepted: June 11, 2018

Published: June 14, 2018

Copyright $\odot 2018$ by authors and Scientific Research Publishing Inc. This work is licensed under the Creative Commons Attribution International License (CC BY 4.0).

http://creativecommons.org/licenses/by/4.0/

\begin{abstract}
Gamification is a solution applied in the main companies of the world. The objective was to discuss the patentability of gamification in the Brazilian Patent Office (INPI). This article reviewed the scientific literature, patent office guidelines and related websites. The documents consulted have shown that patentability criteria are similar among patent offices worldwide; American and European offices have patents related to gamification; the justifications presented by these offices for patenting the inventions related to Gamification are in line with the criteria presented in the guidelines of the Brazilian Patent Office (INPI). Therefore, the present article concluded that inventions related to Gamification meet the patentability criteria of the INPI.
\end{abstract}

\section{Keywords}

Gamification, Patents, Patents Office, Patentability

\section{Introduction}

The Gamification means the use of dynamic and game mechanics to engage people in a system. For Huotari \& Hamari (2012) it is the process that improves services and systems making its use pleasant and intrinsically motivating. The Gamification is a technological trend in the world (Burke, 2012). Global companies use Gamification to improve its systems and services. This process solves problems in the health industry, education, software, and services. The market estimates a revenue of 5 billion dollars with the Gamification in 2018 (Burke, 2012).

Innovative companies treat the Gamification as intangible assets-which has no physical existence-that generates economic benefits. The implementation or 
innovation with the Gamification increased the market value of the companies. Therefore, they seek exclusive exploitation rights-patents, copyright, software, etc.-of these intangibles assets to gather advantage in the market. The patent of a disruptive and innovative technology protects the product from competitors and increase the value of the company, whereas the intangibles assets (patents) are $90 \%$ of the assets of a global company (Hoflinger, 2017).

The patent protects the assets of competitors for a specified period. In addition, patents indicate innovation and production of technological force of a company or country (Narin, Noma, \& Perry, 1987). The patent registration has assessment criteria defined by the intellectual property laws of each country. Intellectual property, according to the Paris Convention (1883), is a set of rights concerning industrial designs and manufactured or natural products. The WIPO Convention (1967) encompasses the intellectual activity in the industrial, artistic, literary and scientific fields. Therefore, the patent is the protection of a product or service with an inventive act, novelty and industrial application (Law No. 9279, 1996).

The intellectual property offices of each country have autonomy to judge the patentability of an invention. These demonstrate differences in the analysis of the criterion of industrial applicability and exclude some intellectual activities of right of a patent. Some countries argue the patentability of Gamification related technologies, for example, the Patent Office of Germany considers the Gamification a business method or mathematician, who is among the non-patentable. On the other hand, inventors have patented the Gamification-in the United States, Japan, and European countries-as a process related to other technologies.

In Brazil, the Office responsible for registering patents is the INPI (National Institute of Intellectual Property). The registry related to the Gamification patent does not exist at INPI. Some experts in the science of Intellectual Property report that the Gamification is an educational or business method (Coordination of innovation and conveyance of technology_CINTTEC, 2018)-industrial property law excludes methods of patentability-and advice copyright protection. However, no company or inventor deposited this type of process (Gamification) at the INPI. While in the US and Europe there are patents related to (Hoflinger \& Zimmerling, 2016; Menezes, Bortoli, \& Almeida, 2017) with features of process patent. However, the Court rejected some recent submissions of Gamification patents. Thus, the goal is to discuss the patentability of the Gamification in INPI.

\section{Methodology}

This work was a documentary research carried out with peer reviewed scientific articles; official sites of the patent offices of the United States, Europe and Brazil; Guidelines and Laws of the National Institute of Intellectual Property (INPI) and the United States; gray literature. The researchers identified the patentability criteria of the three patent offices; the justifications of patent offices that already 
have patents related to gamification; analyzed the laws and guidelines of the INPI for process patents; finally they made the relation of the criteria for an invention related to Gamification to be patentable in Brazil.

\section{Results and Discussion}

\subsection{Gamification}

Gamification is a trend present in the primary mechanisms to transform business operations in $40 \%$ of the top 1000 Global Organizations (Burke, 2012). M2 Research (2011) stated that the size of the market in 2016 was 2.8 billion dollars. Consequently, this economic impact in different industries that Hoflinger \& Zimmerling (2016) detected, companies are interested in marketing your products and services with Gamification with patent protection. The IT companies and the U.S. lead the deposit of Gamification patents.

The first definition of Gamification was using elements of video games outside the context of the games (Deterding et al., 2011). Then Huotari and Hamari (2012) defined the Gamification as a process to improve a service providing a gaming experience in order to support the creation of value by the user. Finally, the Gamification is a process of technical elements present in games to improve a product or service through the creation of game experience, stimulation of motivation and engagement. The technical components of games are feedback system - points, social networks, score table, comments, etc. (Hamari \& Koivisto, 2015)—rules, goals and interface.

Polls indicate the nature of this Gamification field of study ranges from mobile applications, health to engineering and education (Hakulinen, Auvinen \& Korhonen, 2013; McCallum, 2012; Seaborn \& Fels, 2015; Zimmerling et al,, 2016). Recent polls show the fragmentation of technological innovation of the Gamification. A large number of patents presents the Gamification incorporated as part of the novelty of the invention. Hoflinger (2017) showed that the Gamification is inside of existing technologies, for example, as a central component of a specific device or related data.

The Gamification publications in Brazil are-for the most part-from the education field. The authors apply the Gamification as an educational method and, in some studies confuse Gamification with video game seriously. On the market, some companies introduced the Gamification in services and products, but none sought to protect their innovation with patent and software registry (search performed in 2017 in the INPI).

\subsection{Patents}

The patent is the sole right (of a person or company) to use a particular technology. Competitors are legally excluded from economic exploitation of a specific invention by the patent holder (Hall, 2007). This right encourages inventors to develop research and innovation of high cost and risk (Aoki \& Schiff, 2008). Therefore, protection and security against imitations encourage companies to 
patent. In addition, this scenario provides increased profits and competitive advantage over competitors (Blind et al., 2006).

The patent is an intangible asset. They are parsed by each country patent offices (INPI, USPTO, EPO, etc.). The patentability criteria are novelty, inventive act and industrial application. The patent is set to exclusive and lacking comparability allowing routine and fair valuation of the patent (Hagiu \& Yoffie, 2011). These comparisons have estimated the economic value of an asset on the market. Further, the patent depends on additions to have market value, since a single patent is difficult to defend against infringement (Parchomovsky \& Wagner, 2005). Ergo, tech companies record a set of patents to produce freely and market their product. Despite this patents value and the complexity of their management, each technology requires a specific evaluation.

Intangible assets outweigh the value and contribution of physical assets for the development of the company (Lev, 2000). Intellectual property is around $90 \%$ of the value of the main companies in the world (Pricewaterhousecoopers, 2003). The Patent Office of the USA reported that intellectual property is responsible for producing $\$ 5.06$ billion or $34 \%$ of the gross domestic product of the United States in 2010 (Blank \& Kappos, 2012), and the patent is an indicator of production innovation at the company.

The Brazilian Patent Office (INPI) reports on resolution No. 169 (2016) that the application for a patent shall produce: the technical character, the technical problem, and the technical result. The requirements of patentability applied are the same as those of other countries. However, the matters not considered inventions defined in the Brazilian resolution differ from the American (for example). Therefore, despite the national intellectual property laws are in the TRIPs agreement, each country is free to include or remove any item.

\subsection{Patents Related to Gamification}

Patent mapping is a type of study that can indicate the technological development of an area. Gamification related patents have been mapped by two studies, but the number of deposits was low in those polls. However, the analysis of the patentability of these deposits is affected, since many entries did not meet the time required to be granted or rejected. The discussion on the patentability of Gamification in literature is in its early stages. The Gamification is a concept by definition that did not reach the criteria for patentability in some offices.

Menezes et al. (2017) mapped the Gamification related patents. They collected data only from the web of knowledge until the year of 2015. The authors found the US as the largest depositor; companies were mostly in the area of computer engineering; most patents were registered in classes for methods or systems targeted to the business sector (G06Q-050/10), but also in video game category (A63F-013/00) and interconnection between games (A63F-013/30). Nevertheless, the study has some limitations, because collected data only in a database.

The first study was Hoflinger \& Zimmerling (2016) performed a prospecting 
in three databases-USPTO (United States Patent and Trademark Office), EPO (European Patent Office) and on Google Patents research-during the same period of the previous study. However, the results about the country the patented the largest amount, the chosen classification and area businesses were similar. However, the study has limitations in the description of the methodology and results.

\subsection{Patentability of Gamification}

The criteria of patentability between the American, European and Brazilian Laws are similar, but only the first two has patent related to Gamification (nothing in Brazil deposited until 2018 with the exception of those in the period of confidentiality. The American office guideline-patent analysis-defines process as a method, so in many process patents is seen in the title the word method. The three patent offices define that methods in the sense of scheme or description of a procedure are not patentable because do not reach the criterion of utility or industrial application. However, it's patentable as a process or operation with a clear purpose to solve or improve a technical part of a machine or develop a product; and a set of inventions arranged and combined in ways never done before.

The Gamification solves technical problems of software such as the user engagement in the software; identifies the behaviors needed to use the software; the motivating factors for these behaviors; improves the software usability. The implementation of a method by a computer program isn't attend the patent requirements of novelty and inventive step. Even in the US there is a debate about the patentability of business methods, which when applied alone are not considered patents, but copyright or a brief description of steps. However, the process is patentable when combined with a device to solve a technical problem or improve another program or device. In the USA and in other countries there is also the discussion if the business methods can be patented. Most, including the United States, consider the patent the combination of solutions that result of a solution to a technical problem.

The concept of utility or industrial application to the USPTO is the condition that the patent must have a useful purpose, and the operation must meet or run this purpose (USPTO, 2018). Similarly, to USPTO, the law and the Brazilian resolutions demonstrate the patentability (novelty, inventive step and industrial application) of inventions relating to Gamification. For this, the inventor must report on the claims of a patent the technical character of the solution, which solves the technical problem and result expected by the patent. The process is a set of technical solutions rearranged only for solving the technical problem set before.

The European patent guide excerpt is similar to the new resolution No. 169 2016 of INPI's in relation to the patentability of computer programs (EPO, 2018). Both say that a computer program implementing a mathematical method will bring a contribution and a technical effect on the computer. For a computer program be patentable must have a method to solve a technical problem. On the 
other hand, not all software entries as patents have been accepted in the United States since the Alice's case in 2014 (Inventa International, 2015). Therefore, companies should think about the strategy to protect their inventions and have the right to prevent others from copying their technology. Even those companies that already have the grant of patents, they run the risk of losing them, because the jurisprudence of cases judged recently against the patenting of software.

Thus, the patentability criteria should appear in the patent claims (Ex: patent application). The patent owner must write the patent process as a sequence of steps describing the functionality achieved. In addition, the figures complement the description of the claims describing the flow of solutions of a technical problem-flowchart (Resolução N 169, 2016).

\section{Conclusion}

This article presents the patentability of inventions relating to Gamification in the world and in Brazil. The authors demonstrate the character and technical effect of the process related to the Gamification, which meets the requirements of the patent process at INPI. However, they demonstrate cases of Gamification solutions that did not solve a technical problem and fits in business or educational methods. Therefore, the Gamification related to solving a technical problem should be protected as patent.

\section{References}

Aoki, R., \& Schiff, A. (2008). Promoting Access to Intellectual Property: Patent Pools, Copyright Collectives, and Clearinghouses. R\&d Management, 38, 189-204. https://doi.org/10.1111/j.1467-9310.2008.00502.x

Blank, R., \& Kappos, D. (2012). Intellectual Property and the U.S. Economy: Industries in Focus, Economics and Statistics and Administration and the United States Patent and Trademark Office.

https://www.uspto.gov/learning-and-resources/ip-motion/intellectual-property-and-us -economy

Blind, K., Edler, J., Frietsch, R., \& Schmoch, U. (2006). Motives to Patent: Empirical Evidence from Germany. Research Policy, 35, 655-672.

https://doi.org/10.1016/j.respol.2006.03.002

Burke, B. (2012). Gamification 2020: What Is the Future of Gamification. Gartner. https://www.gartner.com/doc/2226015/Gamification--future-Gamification

Coordenação de Inovação e Transferência de Tecnologia-CINTTEC (2018). Formulário de avaliação para depósito de pedido de patente do "Processo de mudança de comportamento gamificado". Aracaju: Comissão de Propriedade Intelectual e Transferência de Tecnologia da Universidade Federal de Sergipe.

Deterding, S., et al. (2011). Gamification: Toward a Definition. C. Gamification Workshop Proceedings, Vancouver, BC, 7-12 May 2011, 1-4.

European Patent Office (EPO) (2018) Guidelines for Examination. http://www.epo.org/law-practice/legal-texts/html/guidelines/e/g_ii_3_6.htm

Hagiu, A., \& Yoffie, D. B. (2011). Intermediaries for the IP Market. Boston, MA: Harvard Business School.

Hakulinen, L., Auvinen, T., \& Korhonen, A. (2013). Empirical Study on the Effect of 
Achievement Badges in TRAKLA2 Online Learning Environment. Learning and Teaching in Computing and Engineering (LaTiCE), Macau, 21-24 March 2013, 47-54. https://doi.org/10.1109/LaTiCE.2013.34

Hall, B. H. (2007). Patents and Patent Policy. Oxford Review of Economic Policy, 23, 568-587. https://doi.org/10.1093/oxrep/grm037

Hamari, J., \& Koivisto, J. (2015). Why Do People Use Gamification Services? International Journal of Information Management, 35, 419-431. https://doi.org/10.1016/j.ijinfomgt.2015.04.006

Hoflinger, P. J. (2017). Gamification in Proprietary Innovation: Identifying a Technical Framework Based on Patent Data. In Proceedings of the 50th Hawaii International Conference on System Sciences (pp. 1288-1297). Honolulu, HI: University of Hawaii. https://doi.org/10.24251/HICSS.2017.154

Hoflinger, P. J., \& Zimmerling, E. (2016). Monitoring Gamification in International Patent Documents: Technology Classes, Firms and Preliminar Value Indicators. In Proceedings of the 49th Hawaii International Conference on System Sciences (pp. 1319-1327). New York, NY: Institute of Electrical and Electronics Engineers. https://doi.org/10.1109/HICSS.2016.167

Huotari, K., \& Hamari, J. (2012). Defining Gamification: A Service Marketing Perspective. In Proceeding of the 16th International Academic MindTrek Conference (pp. 17-22). New York, NY: ACM.

Inventa International (2015). Patentes de Software e Pokémon Go. https://inventa.com/pt/ao/noticias/artigo/172

Law No. 9279, de 14 de maio de 1996 (1996). Regula direitos e obrigaçóes relativos à propriedade industrial. http://www.planalto.gov.br/ccivil_03/leis/19279.htm

Lev, B. (2000). Intangibles: Management, Measurement, and Reporting. Brookings, SD: Brookings Institution Press.

McCallum, S. (2012). Gamification and Serious Games for Personalized Health. Studies in Health Technology and Informatics, 177, 85-96.

Menezes, C., Bortoli, R., \& Almeida, C. P. (2017). Mapeamento tecnológico de patentes relacionadas a gamificação. Revista Eletrônica de Biblioteconomia e Ciência da Informação, 22, 33-41.

M2 Research (2011). Gamified Engagement: Gamification Market to Reach \$2.8 Billion in US by 2016, According to New Findings. http://m2research.com/gamification

Narin, F., Noma, E., \& Perry, R. (1987). Patents as Indicators of Corporate Technological Strength. Research Policy, 16, 143-155.

Parchomovsky, G., \& Wagner, R. P. (2005). Patent Portfolios. University of Pennsylvania Law Review, 154, 1-77.

Pricewaterhousecoopers (2003). Building and Enforcing Intellectual Property Value. An International Guide for the Boardroom.

Resolução No. 169 de julho de 2016 (2016). Dispões sobre as diretrizes de exame de pedido de patentes-bloco II-patenteabilidade.

Seaborn, K., \& Fels, D. I. (2015). Gamification in Theory and Action: A Survey. International Journal of Human-Computer Studies, 74, 14-31.

United States Patent and Trademark Office (USPTO). General Information Concerning Patents.

https://www.uspto.gov/patents-getting-started/general-information-concerning-patent s\#heading-2

Zimmerling, E., Höflinger, P. J., Sandner, P. G., \& Welpe, I. M. (2016). A System Framework for Gamified Cost Engineering. Information Systems Frontiers, 18, 1063-1084. 